\title{
Retinal tubercle. Evolution by OCT and fundoscopy
}

\section{Tubérculo retiniano. Evolución a través de OCT y fundoscopia}

\author{
Javier Lacorzana ${ }^{1,2 *}$ and José L. García-Serrano ${ }^{3}$
}

${ }^{1}$ Department of Ophthalmology, Hospital Virgen de las Nieves; ${ }^{2}$ Doctoral Program in Clinical Medicine and Public Health, University of Granada; ${ }^{3}$ Department of Ophthalmology, Hospital San Cecilio. Granada, Spain
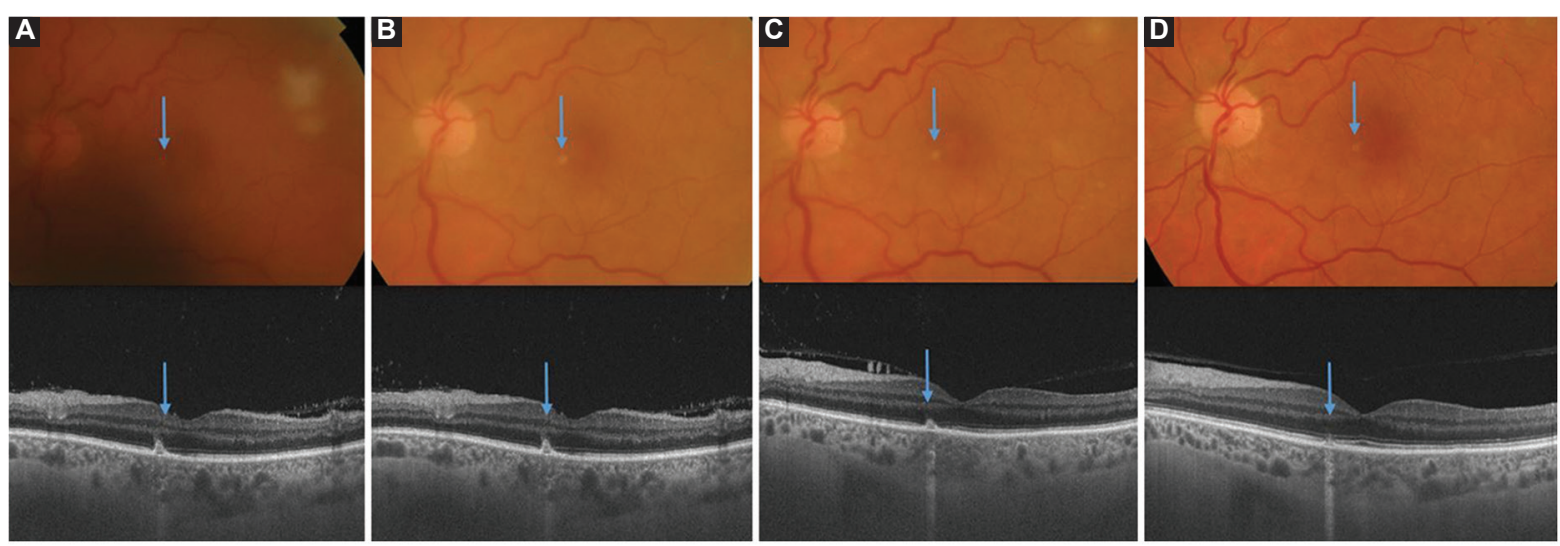

Figure 1. A: before treatment. B: one week after treatment initiation; the macular tubercle is in the process of remission. C: two weeks after treatment initiation. D: three months after treatment initiation; the lesion has disappeared and a zone of juxtafoveal atrophy is observed.

We present the evolution and response to treatment of a 58-year-old patient with a retinal tuberculoma using optical coherence tomography (OCT). The patient had a medical history of hepatitis $\mathrm{C}$ virus infection, latent tuberculosis, and a cardiac valve prosthesis, and was diagnosed with bilateral ocular tuberculosis. The study only shows the evolution of the eye most affected by tuberculosis.

By fundoscopy, a white spot was observed in the macular area, as well as a tuberculoma in the outer layers of the retina by OCT (Fig. 1). Positive immunological and intradermal tests confirmed the diagnosis of tuberculosis. The patient was started on antituberculosis treatment $(150 \mathrm{mg}$ of rifampicin, $75 \mathrm{mg}$ of isoniazid, $400 \mathrm{mg}$ of pyrazinamide and $275 \mathrm{mg}$ of ethambutol), plus oral and topical corticosteroids, achieving complete recovery after 3 months.

\section{Conflicts of interest}

The authors declare no conflicts of interest.

\section{Correspondence:}

*Javier Lacorzana

Av. de las Fuerzas Armadas, 2

Date of reception: 03-04-2020

Date of acceptance: 01-07-2020

E-mail: javilacor@gmail.com

2604-1731/@ 2020 Sociedad Mexicana de Oftalmología. Published by Permanyer. This is an open access article under the CC BY-NC-ND license (http://creativecommons.org/licenses/by-nc-nd/4.0/). 


\section{Ethical disclosures}

Protection of human and animal subjects. The authors declare that the procedures followed were in accordance with the regulations of the relevant clinical research ethics committee and with those of the Code of Ethics of the World Medical Association (Declaration of Helsinki).
Confidentiality of data. The authors declare that they have followed the protocols of their work center on the publication of patient data.

Right to privacy and informed consent. The authors have obtained the written informed consent of the patients or subjects mentioned in the article. The corresponding author is in possession of this document. 